\title{
Both timeless and new: Behind the scenes of locally grown food
}

\author{
Film review by Angela Glore* \\ Community Food Council for Del Norte \\ County and Adjacent Tribal Lands
}

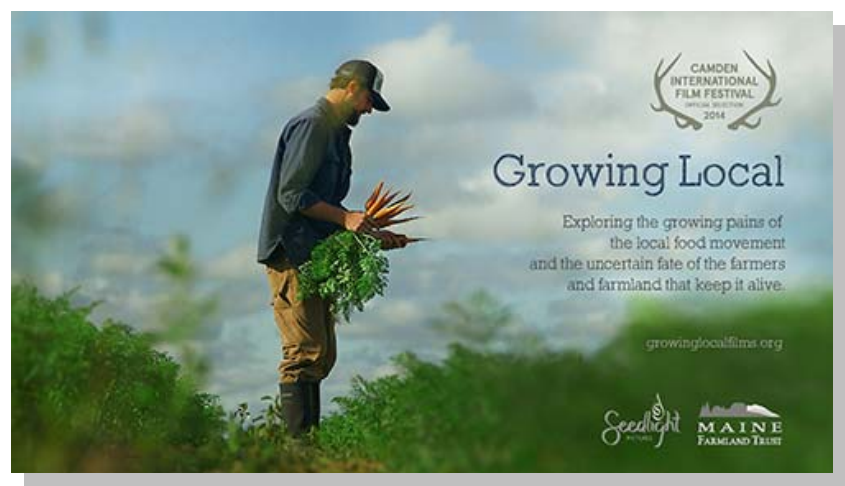

\author{
Review of Growing Local film series, directed by Bridget Besaw. \\ (2015). Executive producer Bridget Besaw. Limited release. Film's \\ website: http://www.growinglocalfilms.org
}

Submitted September 1, 2015 / Published online December 17, 2015

Citation: Glore, A. (2015). Both timeless and new: Behind the scenes of locally grown food [Film review].

Journal of Agriculture, Food Systems, and Community Development, 6(1), 215-216.

http://dx.doi.org/10.5304/jafscd.2015.061.018

Copyright (C) 2015 by New Leaf Associates, Inc.

$\mathrm{E}$ ach time I watch the Growing Local trilogy of short films, my heart feels like I've chosen the wrong profession. The early-morning-mist beauty of these films makes one yearn for more direct participation with farms, farmers, and the business of providing real food to real people.

For many people, the public face of local food is their local farmers markets: the hands ingrained

\footnotetext{
* Angela Glore, Community Food Council for Del Norte County and Adjacent Tribal Lands; 494 Pacific Avenue; Crescent City, California 95531 USA; angela.glore@gmail.com

Angela Glore is a member of the Community Food Council for Del Norte County and the Adjacent Tribal Lands, and represents California's North Coast on the steering committee for the California Food Policy Council. She holds a master's and doctorate in anthropology from Washington University in St. Louis, where she studied food and farming in North America's past and present.
}

with dirt stacking a bountiful rainbow of vegetables and fruit on tables shaded by the ubiquitous popup canopy. The Growing Local films showcase some of the other faces of local food: the retiring dairy farmer struggling with how to transfer the farm to his son; the accidental butcher providing fair middle-man services to his meat-producing neighbors; the young couple who feel they were born in the wrong time, creating a vibrant hub for local food and community.

Growing Local is a collaboration between Seedlight Pictures (Bridget Besaw, executive producer and director) and Maine Farmland Trust. Each of the three shorts highlights a single Maine farmer or farm family to represent a pressing issue in small farm life.

Changing Hands, the story of the Beal family and Rocky Ridge Organic Dairy Farm, is at times 
tense, as father and son acknowledge their different ways of farming and the financial difficulties in transferring farmland from one generation to the next. As the film points out, 400 million acres (162 million hectares) of land across the United States will be changing hands as farmers retire over the next decade or so, and self-employed farmers often have their retirement funds tied up in the land and equipment. The senior Farmer Beal says it plainly: "The farm is my retirement. I can't just give it to him."

In Pig, Not Pork, change is in the system, not the farm. Ben and Erin, former meat producers, run Farmers Gate Market, a butcher shop linking consumers to a network of local, small-scale livestock producers. Farmers Gate Market is an indirect market for local foods - a shift from the face-to-face transactions consumers have grown used to. Ben wonders aloud if there's enough money in the price difference between his roast and an industrially produced roast for his business to survive. Increasing the scale of local food production will require fair middle-men like Ben so that, as one of his suppliers says, producers can concentrate on what they do best: produce good food.

Seeding a Dream, the last of the short films, weaves together several issues raised in Changing Hands and Pig, Not Pork. Ben and Taryn lease land and buildings on land protected by an agricultural easement. Ben farms and sells at farmers markets while Taryn operates Sheepscot General, a store, restaurant, bakery, library, live music venue, and community space. The former landowner wrote the conservation easement himself, with the intent that the land would be actively used for food or fiber production in perpetuity. The current owner leases to Ben and Taryn to honor that intent and sees them as his own children as they work together to forge a lease-to-buy arrangement. Without the access to land this arrangement allows, Taryn and Ben could not have created the community that has grown up around Sheepscot General, something both timeless and brand new.

The Growing Local films are a testament to local food producers whose livelihoods are dependent on weather and soil and the fickle whimsies of consumers. A message repeated throughout the films is that consumers need to change as much or more than producers in order to fully realize a strong local food economy. Consumers have become used to artificially low food prices. As Ben the butcher muses: we eat three meals a day and see a doctor once a year, so why do we put a higher value on the doctor's services than the food producer's?

Taken together these films demonstrate that the building blocks for a relocalized food economy exist. Putting them together may not be easy, or come quickly, but we have the pieces if we collectively have the will. The families featured in Growing Local don't have all the answers, but they have found solutions, or are working toward them, for their farms, in their communities.

Who should watch this collection of films? People in the trenches of the good food/local food movement should watch them for inspiration, to shake themselves out of occasional doubt, and to reimagine the possible. Local food consumers should watch to understand better why local food often costs more than industrially produced food, and to be inspired to commit to change. Communities should watch together and push for local, state, and federal policies that encourage more small farms and small-scale food hubs. These films are a reminder of the unceasing work required to feed America every day — and we can all use one of those. 